\title{
Faktor - Faktor Yang Mempengaruhi Profitabilitas Dan Dampaknya Terhadap Manajemen Laba
}

\author{
Agustina, Sulia, Rice \\ Sekolah Tinggi Ilmu Ekonomi Mikroskil \\ agustina@mikroskil.ac.id
}

\begin{abstract}
This study examine the influence of debt to equity ratio, firm size, institutional ownership, public ownership, independent board and audit committee on profitability and the impact for earning management. Population for this study was 65 natural resource company listed in Indonesia Stock Exchange Period 2012-2015. Based on purposive sampling method, 21 natural resource company was selected (or 84 observation). Data was selected from the companies' financial reports and analysed by using path analysis. This study found that debt to equity ratio, firm size, institutional ownership, public ownership, independent board and audit committee simultaneously affect profitability and earning management. Partialy, only independent board affect profitability and only institutional ownership and public ownership affect earning management. Futhermore, profitability can only mediate the affect of institutional ownership, public ownership and independent board to earning management.
\end{abstract}

Keyword: profitability, earning management, natural resources company

\begin{abstract}
Abstrak: Penelitian ini bertujuan untuk menguji pengaruh debt to equity ratio, ukuran perusahaan, kepemilikan institusional, kepemilikan publik, dewan komisaris independen dan komite audit terhadap profitabilitas dan dampaknya terhadap manajemen laba. Populasi penelitian berjumlah 65 perusahaan sumber daya alam yang terdaftar di Bursa Efek Indonesia periode 2012-2015. Dengan teknik purposive sampling, diperoleh sebanyak 21 perusahaan (84 data pengamatan). Data diperoleh dari laporan keuangan perusahaan dan kemudian dianalisis dengan menggunakan analisis jalur Hasil penelitian menunjukkan bahwa variabel debt to equity ratio, ukuran perusahaan, kepemilikan institusional, kepemilikan publik, dewan komisaris independen dan komite audit secara simultan berpengaruh terhadap profitabilitas dan manajemen laba. Secara parsial, hanya dewan komisaris independen yang berpengaruh terhadap profitabilitas dan hanya kepemilikan institusional dan kepemilikan publik yang berpengaruh terhadap manajemen laba. Selain itu, profitabilitas hanya dapat memediasi pengaruh kepemilikan institusional, kepemilikan publik, dan dewan komisaris independen terhadap manajemen laba.
\end{abstract}

Kata kunci: profitabilitas, manajemen laba, perusahaan sumber daya alam

\section{PENDAHULUAN}

Manajemen laba dilakukan oleh manajer atau penyusun laporan keuangan karena perusahaan mengharapkan suatu manfaat dari tindakan yang dilakukan. Manajemen laba dapat memberikan gambaran tentang perilaku manajer dalam melaporkan kegiatan usaha pada suatu periode tertentu, yaitu adanya kemungkinan motivasi tertentu yang mendorong mereka untuk merekayasa data keuangan. Manajemen laba dapat diartikan sebagai sebuah tindakan pemanfaatan trik akuntansi dimana terdapat fleksibilitas dalam penyusunan 
laporan keuangan digunakan atau dimanfaatkan oleh manajer yang berusaha untuk memenuhi target laba. Manajemen laba terjadi bila manajer menggunakan kreativitasnya dalam penyusunan laporan keuangan dan mengatur transaksi untuk merubah laporan keuangan dengan tujuan memberi kesan tertentu atau mempengaruhi tindakan para stakeholders yang bergantung pada laporan keuangan tersebut. Manajemen laba muncul sebagai dampak masalah keagenan yang terjadi karena adanya ketidakselarasan kepentingan antara pemegang saham (principal) dan manajemen perusahaan (agent). Pihak prinsipal termotivasi mengadakan kontrak untuk menyejahterahkan dirinya dengan profitabilitas yang selalu meningkat sedangkan agen termotivasi untuk memaksimalkan pemenuhan kebutuhan ekonomi dan psikologisnya, antara lain dalam hal memperoleh investasi, pinjaman, maupun kontrak kompensasi. Dalam kondisi seperti ini diperlukan suatu mekanisme pengendalian yang dapat mensejajarkan perbedaan kepentingan antara kedua belah pihak.

Di Indonesia sendiri, praktik manajemen laba boleh dikatakan sudah tidak asing lagi, sebagai contoh kasus PT. Bank Negara Indonesia Tbk (BBNI) di tahun 2003 yang telah melakukan pencadangan dana fiktif sebesar Rp 1,7 triliun. Di mana diinformasikan bahwa perusahaan telah memperoleh laba bersih sebesar Rp 2,8 triliun di tahun 2003, padahal secara nyata, hanya seperenam dari laba bersih tersebut yang terealisasi (www.bumn.go.id). Bukan hanya BBNI, di tahun 2010 terungkap kasus manipulasi informasi yang dilakukan oleh manajer PT. Bakrie \& Brother Tbk (BNBR), PT. Bakrie Sumatera Plantations Tbk (UNSP) dan PT. Energi Mega Persada Tbk (ENRG) terkait selisih dana simpanan ketiga perusahaan di PT. Bank Capital Tbk (BACA). Berdasarkan laporan keuangan kuartal pertama dari BNBR yang menyatakan bahwa terdapat simpanan dana sebesar Rp 3,75 triliun, UNSP sebesar Rp 3,50 triliun dan ENRG sebesar Rp 1,34 triliun, serta beberapa anak perusahaan sekitar Rp 9,05 triliun, yang apabila dijumlahkan adalah sebesar Rp 17,64 triliun. Namun berdasarkan laporan dari BACA, jumlah simpanan nasabah pada periode yang sama hanya berkisar Rp 2,17 triliun, yang artinya terdapat selisih sebesar Rp 15,47 triliun dana simpanan menurut ketiga perusahaan yang tidak tercatat dalam laporan BACA (www.republika.co.id). Selang waktu satu tahun, yaitu di tahun 2011, kembali terungkap kasus penyalahgunaan cadangan dana PT. Elnusa yang menyebabkan perusahaan seolah memiliki potensi meraih keuntungan yang cukup tinggi, namun sebenarnya perusahaan berada dalam kondisi krisis (www.detik.com).

Penelitian ini diawali dengan mengangkat fenomena terjadinya manajemen laba pada beberapa perusahaan di Indonesia, dan kemudian mencoba mengkaji kembali faktor faktor apa saja yang mempengaruhi manajer dalam melakukan tindakan manajemen laba khususnya pada perusahaan sumber daya alam yang terdaftar di Bursa Efek Indonesia. Hal ini mengingat bahwa perusahaan sumber daya alam merupakan perusahaan yang memperoleh manfaat terbesar dari hasil-hasil alam, dan cenderung wajib bertanggungjawab penuh terhadap masyarakat sekitarnya mengenai kegiatan operasional. Sehingga manajer cenderung akan mencoba untuk memberikan gambaran terbaik mengenai perusahaan yang dikelola. Relevansi manajemen laba dengan profitabilitas adalah informasi laba dapat dimanipulasi oleh manajer untuk meningkatkan reputasi perusahaan apabila laba perusahaan rendah. Berdasarkan kajian teori, terdapat beberapa faktor yang dapat mempengaruhi manajemen laba, antara lain rasio leverage, ukuran perusahaan dan tata kelola perusahaan.

Rasio leverage dalam penelitian ini diproksikan dengan Debt to Equity Ratio. Debt to Equity Ratio (DER) adalah rasio leverage yang membandingkan jumlah penggunaan 
hutang dengan ekuitas dalam memenuhi kegiatan operasional perusahaan. Perusahaan yang mempunyai debt to equity ratio yang tinggi, berarti proporsi hutangnya lebih tinggi dibandingkan dengan proporsi ekuitasnya yang akan cenderung melakukan manipulasi dalam bentuk manajemen laba. Hal ini disebabkan karena perusahaan ingin memberikan kepercayaan kepada investor hutang akan kemampuan dalam pembayaran hutang. Hasil penelitian Afriandi dan Wahidahwati (2013) yang menunjukkan bahwa debt to equity ratio berpengaruh terhadap manajemen laba. Akan tetapi, berbeda dengan hasil penelitian Pradipta (2011) yang menunjukkan bahwa debt to equity ratio tidak berpengaruh terhadap manajemen laba.

Faktor lain yang dapat menyebabkan terjadinya tindakan manajemen laba yaitu ukuran perusahaan yang bersangkutan. Pada umumnya perusahaan yang besar memiliki peluang yang cukup besar untuk melakukan manajemen laba. Hal ini dikarenakan perusahaan besar harus mampu memenuhi ekspektasi dari investor dan pemegang sahamnya. Di samping itu dengan semakin besarnya suatu perusahaan cenderung akan lebih kompleks aktivitas operasionanya, sehingga akan menyebabkan meningkatnya peluang terjadinya tindakan-tindakan yang menguntungkan pihak-pihak tertentu apabila tidak didukung dengan semakin membaiknya kontrol internal. Hasil penelitian Sirat (2012) yang menunjukkan bahwa ukuran perusahaan berpengaruh terhadap manajemen laba. Akan tetapi, berbeda dengan hasil penelitian Sosiawan (2012) yang menunjukkan bahwa ukuran tidak berpengaruh terhadap manajemen laba.

Oleh karena semakin meningkatnya tindakan manajemen laba, maka diharapkan perusahaan dapat menerapkan tata kelola perusahaan yang baik. Tata kelola perusahaan adalah serangkaian kebijakan perusahaan agar kegiatan operasi perusahaan berjalan sesuai dengan harapan para pemangku kepentingan (stakeholders). Salah satu penerapan tata kelola perusahaan yang baik yaitu adanya pemisahkan kepemilikan terhadap perusahaan. Dengan adanya pemisahan kepemilikan maka akan dapat meningkatkan kontrol terhadap tindakan manajer perusahaan. Hasil penelitian Widyastuti (2009) yang menunjukkan bahwa kepemilikan perusahaan oleh institusional berpengaruh terhadap manajemen laba. Akan tetapi, berbeda dengan hasil penelitian Agustia (2013) yang menunjukkan bahwa kepemilikan institusional tidak berpengaruh terhadap manajemen laba. Di samping itu hasil penelitian Suhartanto (2015) yang menunjukkan bahwa kepemilikan publik tidak berpengaruh terhadap manajemen laba. Selain itu, dengan adanya dewan komisaris independen juga diharapkan dapat membantu mengontrol tindakan manajer perusahaan. Hasil penelitian Rahmawati (2013) yang menunjukkan bahwa dewan komisaris independen berpengaruh terhadap manajemen laba. Akan tetapi, bertentangan dengan hasil penelitian Agustia (2013) yang menunjukkan bahwa dewan komisaris independen tidak berpengaruh terhadap manajemen laba. Salah satu penerapan tata kelola perusahaan yang baik yaitu adanya komite audit yang membantu mengontrol jalannya perusahaan apakah sudah sesuai dengan ketentuan yang telah ditetapkan. Hasil penelitian Suriyani et al (2015) yang menunjukkan bahwa komite audit berpengaruh terhadap manajemen laba. Akan tetapi, bertentangan dengan hasil penelitian Rahmawati (2013) yang menunjukkan bahwa komite audit tidak berpengaruh terhadap manajemen laba.

Tujuan penelitian ini adalah untuk mendapatkan bukti empiris mengenai faktor faktor yang mempengaruhi manajemen laba dengan profitabilitas sebagai variabel intervening pada perusahaan sumber daya alam yang terdaftar di Bursa Efek Indonesia periode 2012 sampai 2015. Penelitian ini diharapkan dapat memberikan manfaat untuk 
pengembangan ilmu pengetahuan terlebih ilmu akuntansi mengenai tindakan manajemen laba.

\section{KAJIAN TEORI}

Profitabilitas. Rasio profitabilitas adalah rasio untuk menilai kemampuan perusahaan dalam mencari keuntungan. Rasio profitabilitas juga memberikan ukuran tingkat efektivitas manajemen perusahaan yang ditunjukkan oleh laba yang dihasilkan dari penjualan dan pendapatan investasi (Kasmir, 2012). Penggunaan rasio profitabilitas dapat dilakukan dengan menggunakan perbandingan antara berbagai komponen yang ada di laporan keuangan, terutama laporan keuangan neraca dan laporan laba rugi. Pengukuran dapat dilakukan untuk beberapa periode operasi agar dapat terlihat perkembangan perusahaan dalam rentang waktu tertentu. Setelah mengetahui hasil perkembangan perusahaan, maka akan dijadikan alat evaluasi kinerja manajemen selama ini. Bila sudah berjalan dengan baik, maka harus dipertahankan untuk menjadi lebih baik, tetapi bila tidak berjalan dengan baik, maka pihak manajemen harus memperbaikinya. Oleh karena itu, rasio ini sering disebut sebagai salah satu alat ukur kinerja manajemen. Profitabilitas dapat dikur dengan sejumlah cara yang salah satunya dengan rasio Return On Asset (ROA). Rasio ini dihitung dengan membandingkan nilai laba bersih setelah pajak terhadap total assetnya.

Manajemen Laba. Skandal akuntansi dan manajemen laba adalah bagian dari akuntansi keuangan karena berhubungan dengan pihak luar atau kepentingan banyak pihak di luar perusahaan (Sulistiawan, dkk, 2011:4). Schipper (1989) menyatakan bahwa manajemen laba dapat didefinisikan sebagai "intervensi manajemen dengan sengaja dalam proses penentuan laba, biasanya untuk memenuhi tujuan pribadi" (Subramanyam dan Wild, 2010). Manajemen laba dapat terlihat nyata apabila manajer memilih tindakan dengan konsekuensi arus kas dengan tujuan mengubah laba. Motivasi untuk memenuhi target laba dapat membuat manajer atau perusahaan mengabaikan praktik bisnis yang baik. Tindakan manajer tersebut biasanya disebut sebagai tindakan manajemen laba. Manajemen laba merupakan suatu tindakan yang dilakukan oleh manajer perusahaan dengan tujuan mengatur jumlah laba yang dilaporkan. Tindakan manajer tersebut bisa berupa menaikkan, menurunkan atau meratakan laba yang diperoleh (Setyorini and Ishak, 2012).

Leverage. Rasio leverage adalah rasio penggunaan aset dan sumber dana (sources of funds) oleh perusahaan yang memiliki biaya tetap (beban tetap) dengan maksud agar meningkatkan keuntungan potensial pemegang saham. Penggunaan hutang dalam kegiatan pendanaan perusahaan tidak hanya memberikan dampak yang baik bagi perusahaan. Jika proporsi leverage tidak diperhatikan perusahaan, hal tersebut akan menyebabkan turunnya profitabilitas karena penggunaan hutang menimbulkan beban bunga yang bersifat tetap. Debt to Equity Ratio (DER) merupakan rasio leverage yang menunjukkan persentase penyediaan dana oleh pemegang saham terhadap pemberi pinjaman (Darsono, 2005). Semakin tinggi DER, mencerminkan resiko perusahaan relatif tinggi karena perusahaan dalam operasi cenderung tergantung terhadap hutang dan perusahaan memiliki kewajiban untuk membayar bunga hutang yang mengakibatkan laba perusahaan berkurang, sehingga para investor cenderung tergantung terhadap hutang yang mengakibatkan laba perusahaan berkurang. Selain itu, DER yang terlalu tinggi juga tidak baik, karena tiingkat hutang yang 
semakin tinggi akan memperbesar kemungkinan resiko gagal bayar ( risk of default) bunga pinjaman maupun pokok hutang yang akhirnya dapat mengakibatkan kebangkrutan perusahaan.

Ukuran Perusahaan. Ukuran perusahaan dapat ditentukan dari jumlah aset yang dimiliki, laba yang diperoleh perusahaan, dan kapasitas pasar. Semakin besar total aktiva perusahaan, laba yang diperoleh dan kapasitas pasar perusahaan maka semakin besar ukuran perusahaan tersebut. Watts dan Zimmerman (1990) menyatakan bahwa ukuran (skala) perusahaan merupakan variabel penting yang akan menjelaskan pemilihan metode akuntansi. Ukuran perusahaan dapat digolongkan sebagai salah satu unsur dari lingkungan kerja yang akan turut mempengaruhi persepsi manajemen nantinya. Pemilihan sebuah metode akuntansi dapat dipakai sebagai alat untuk mempengaruhi nilai perusahaan (Hery, 2012). Perusahaan yang memiliki ukuran besar akan cenderung memiliki kemudahan dalam memasuki pasar modal. Hal ini mengurangi ketergantungan dana yang dihasilkan dari dalam perusahaan dan memungkinkan pembayaran dividen dengan tingkat yang lebih tinggi (Hery, 2013).

Corporate Governance. Tata kelola perusahaan (corporate governance) adalah serangkaian kebijakan perusahaan agar kegiatan operasi perusahaan berjalan sesuai dengan harapan para pemangku kepentingan (stakeholders). Tujuan penerapan corporate governance adalah memberikan batas tertentu agar pengambil kebijakan di perusahaan tidak melakukan hal-hal yang ilegal atau tidak etis (Syahyunan, 2015). Ada beberapa indikator yang dapat digunakan untuk menilai penerapan corporate governance, seperti: melihat struktur kepemilikan perusahaan (baik oleh pihak institusional atau oleh pihak manajer), jumlah dewan komisaris independen dan jumlah dewan komite audit yang ada di dalam perusahaan. Semakin tingginya harapan konsumen, karyawan, investor, mitra bisnis dan masyarakat lokal akan peran perusahaan telah meningkat. Sehingga pihak perusahaan dituntut untuk semakin meningkatkan transparansi dan akuntabilitas (Toukabri Mohamed, et al, 2014). Salah satu cara agar dapat meningkatkan transparansi dan akuntabilitas perusahaan adalah dengan menerapkan tata kelola perusahaan yang baik.

Berdasarkan kajian teori, hasil penelitian terdahulu, maka hipotesis yang akan diuji dalam penelitian ini adalah sebagai berikut:

Hipotesis 1. Debt to Equity Ratio, Ukuran Perusahaan, Kepemilikan Institusional, Kepemilikan Publik, Dewan Komisaris Independen, dan Komite Audit berpengaruh terhadap Profitabilitas.

Sub Hipotesis:

H1a: Debt to Equity Ratio berpengaruh terhadap Profitabilitas

H1b: Ukuran Perusahaan berpengaruh terhadap Profitabilitas

H1c: Kepemilikan Institusional berpengaruh terhadap Profitabilitas

H1d: Kepemilikan Publik berpengaruh terhadap Profitabilitas

H1e: Dewan Komisaris Independen berpengaruh terhadap Profitabilitas

H1f: Komite Audit berpengaruh terhadap Profitabilitas

Hipotesis 2. Debt to Equity Ratio, Ukuran Perusahaan, Kepemilikan Institusional, Kepemilikan Publik, Dewan Komisaris Independen, dan Komite Audit berpengaruh terhadap Manajemen Laba.

Sub Hipotesis : 
H2a: Debt to Equity Ratio berpengaruh terhadap manajemen laba

$\mathrm{H} 2 \mathrm{~b}$ : Ukuran Perusahaan berpengaruh terhadap manajemen laba

H2c: Kepemilikan Institusional berpengaruh terhadap manajemen laba

H2d: Kepemilikan Publik berpengaruh terhadap manajemen laba

H2e: Dewan Komisaris Independen berpengaruh terhadap manajemen laba

H2f: Komite Audit berpengaruh terhadap manajemen laba

Hipotesis 3. Debt to Equity Ratio, Ukuran Perusahaan, Kepemilikan Institusional, Kepemilikan Publik, Dewan Komisaris Independen, dan Komite Audit berpengaruh terhadap manajemen laba melalui profitabilitas.

Sub Hipotesis:

H3a: Debt to Equity Ratio berpengaruh terhadap manajemen laba melalui profitabilitas

H3b: Ukuran Perusahaan berpengaruh terhadap manajemen laba melalui profitabilitas

H3c: Kepemilikan Institusional berpengaruh terhadap manajemen laba melalui profitabilitas

H3d: Kepemilikan Publik berpengaruh terhadap manajemen laba melalui profitabilitas

H3e: Dewan Komisaris Independen berpengaruh terhadap manajemen laba melalui profitabilitas

H3f: Komite Audit berpengaruh terhadap manajemen laba melalui profitabilitas

\section{METODE}

Jenis penelitian ini merupakan penelitian deskriptif kuantitatif. Penelitian deskriptif kuantatif digunakan untuk menguji dan menjelaskan pengaruh antar fenomena yang ada, dan menggabungkan pengaruh antar variabel yang terlibat didalamnya, kemudian diinterpretasikan berdasarkan teori yang ada dan literatur - literaturnya.

Objek penelitian yang digunakan dalam penelitian ini adalah perusahaan Sumber Daya Alam yang terdaftar di Bursa Efek Indonesia untuk periode 2012-2015, berjumlah 65 perusahaan. Dan dengan menggunakan teknik purposive sampling, diperoleh sebanyak 21 perusahaan untuk dijadikan sebagai sampel. Adapun kriteria yang digunakan dalam pemilihan sampel antara lain : (a) Perusahaan yang berturut-turut termasuk dalam sektor Sumber Daya Alam untuk periode 2012-2015, (b) Perusahaan Sumber Daya Alam yang mempublikasikan laporan CSR selama periode 2012-2015, (c) Laporan keuangan perusahaan disajikan dalam mata uang rupiah, (d) Laporan keuangan menyediakan secara lengkap semua data yang dibutuhkan. Data perusahaan diperoleh melalui website resmi dari Bursa Efek Indonesia (www.idx.co.id).

Model analisis data dalam penelitian ini yaitu analisis regresi linier berganda untuk pengujian hipotesis pertama dan kedua, dan analisis jalur untuk pengujian hipotesis ketiga. Namun sebelum dilakukannya pengujian terhadap model regresi, harus dilakukan pengujian terhadap kualitas data yang digunakan yaitu dengan statistik deskriptif dan uji asumsi klasik.

\section{HASIL DAN PEMBAHASAN}

Berdasarkan hasil pengujian, diperoleh statistik deskriptif untuk masing-masing variabel yang digunakan sebagaimana dijabarkan pada Tabel 1. (sisipkan Tabel 1 di sini) Rata rata profitabilitas perusahaan sumber daya alam yang terdaftar di Bursa Efek Indonesia 
periode 2012 sampai 2015 sebesar 2,750414. Nilai rata-rata yang diperoleh dinyatakan kurang baik, karena berada di bawah rata-rata industri, hal ini menunjukkan bahwa perusahaan kurang mampu memperoleh laba dari pemanfaatan asset yang dimiliki. Rata rata manajemen laba perusahaan sumber daya alam yang terdaftar di Bursa Efek Indonesia periode 2012 sampai 2015 sebesar -0,149414 yang artinya rata-rata perusahaan sampel melakukan tindakan penurunan jumlah laba yang diperoleh.

Rata - rata debt to equity ratio perusahaan sumber daya alam yang terdaftar di Bursa Efek Indonesia periode 2012 sampai 2015 sebesar 138,291435. Nilai yang diperoleh dinyatakan kurang baik, karena berada di atas 50\%, di mana menunjukkan bahwa rata-rata perusahaan sampel cenderung lebih banyak membiayai aktivitas operasional dengan menggunakan hutang.

Rata - rata ukuran perusahaan sumber daya alam yang terdaftar di Bursa Efek Indonesia periode 2012 sampai 2015 sebesar 15,354792 atau sekitar empat triliun rupiah. Hal ini dapat disimpulkan bahwa rata-rata perusahaan sampel merupakan perusahaan yang tergolong besar menurut Undang - Undang Republik Indonesia Nomor 20 tahun 2008 tentang Usaha Mikro, Kecil, dan Menengah.

Rata - rata kepemilikan institusional perusahaan sumber daya alam yang terdaftar di Bursa Efek Indonesia periode 2012 sampai 2015 sebesar 62,586046. Nilai rata - rata yang diperoleh dapat dinyatakan baik, karena berdasarkan rata - rata industri perusahaan, persentase kepemilikan harus lebih besar dari 50\%. Hal ini berarti semakin terkonsentrasinya kepemilikan perusahaan, maka pemegang saham mayoritas akan semakin menguasai perusahaan dan berpengaruh terhadap pengambilan keputusan perusahaan dan lebih efektif dalam melakukan pengawasan.

Rata - rata kepemilikan publik perusahaan sumber daya alam yang terdaftar di Bursa Efek Indonesia periode 2012 sampai 2015 sebesar 34,149269. Nilai rata - rata yang diperoleh dapat dinyatakan kurang baik, karena berdasarkan keputusan Bursa Efek Indonesia, saham emiten ke publik berkisar 15 sampai 20 persen. Nilai rata-rata yang diperoleh sudah jauh berada di atas ketetapan Bursa Efek Indonesia. Hal ini dapat menyebabkan terjadinya fluktuasi harga saham yang mungkin di luar perkiraan, karena pa umumnya investor publik lebih bersifat investor spekulasi. Hal ini berarti semakin tidak terkonsentrasinya kepemilikan perusahaan, maka akan berpengaruh terhadap sulitnya pengambilan keputusan perusahaan.

Rata - rata dewan komisaris independen perusahaan sumber daya alam yang terdaftar di Bursa Efek Indonesia periode 2012 sampai 2015 sebesar 1,82. Nilai rata-rata yang dimiliki dinyatakan kurang baik, karena jumlah komisaris independen tidak banyak, hanya sekitar 2 orang saja, sehingga cenderung lebih sulit melakukan pengontrolan terhadap perusahaan.

Rata - rata komite audit perusahaan sumber daya alam yang terdaftar di Bursa Efek Indonesia periode 2012 sampai 2015 sebesar 3,27. Jumlah rata-rata komite audit yang diperoleh dinyatakan baik, karena menurut Forum for Corporate Governance in Indonesia dan YPPMI Institute minimal terdiri dari 3 orang.

Pengujian Asumsi Klasik. Pada pengujian asumsi klasik untuk hipotesis pertama dan kedua, diperoleh hasil bahwa data yang digunakan mengalami masalah dalam uji normalitas. Oleh karena data yang digunakan dalam penelitian harus memenuhi syarat Best Linier Unbias Estimator (BLUE), maka peneliti melakukan tindakan outlier data. 
Pengujian Hipotesis. Pengujian hipotesis yang dilakukan pertama kali adalah menguji pengaruh variabel independen terhadap profitabilitas, baik secara simultan maupun parsial sebagaimana dijabarkan pada Tabel 2. (sisipkan Tabel 2 di sini)

Berdasarkan hasil simultan, diketahui bahwa debt to equity ratio, ukuran perusahaan, kepemilikan institusional, kepemilikan publik, dewan komisaris independen, dan komite audit berpengaruh terhadap profitabilitas. Hal ini dibuktikan dengan nilai signifikan yang lebih kecil dari $0,05(0,000)$ dan nilai Fhitung $(3,336)$ yang lebih besar dari Ftabel sebesar 2,230 . Dan diketahui bahwa secara parsial, hanya dewan komisaris independen yang berpengaruh signifikan terhadap profitabilitas, sedangkan debt to equity ratio, ukuran perusahaan, kepemilikan institusional, kepemilikan publik, dan komite audit tidak berpengaruh signifikan terhadap profitabilitas.

Persamaan Regresi yang terbentuk :

Profitabilitas $=15,277-$ 0,008Debt to Equity Ratio - 0,406Ukuran Perusahaan + 0,039Kepemilikan Institusional - 0,146Kepemilikan Publik + 3,115 Dewan Komisaris Independen - 1,589 Komite Audit

Berdasarkan hasil pengujian pada Tabel 2 diketahui bahwa secara simultan, debt to equity ratio, ukuran perusahaan, kepemilikan institusional, kepemilikan publik, dewan komisaris independen, komite audit, dan profitabilitas berpengaruh terhadap manajemen laba. Hal ini juga dibuktikan dari nilai signifikan yang diperoleh dibawah $0,05(0,000)$ dan nilai Fhitung $(2,290)$ lebih besar dari nilai Ftabel $(2,230)$. Dan diketahui bahwa secara parsial, hanya kepemilikan institusional dan kepemilikan publik yang berpengaruh signifikan terhadap manajemen laba, sedangkan debt to equity ratio, ukuran perusahaan, dewan komisaris independen, komite audit, dan profitabilitas tidak berpengaruh terhadap manajemen laba. Sedangkan untuk hasil pengujian hipotesis ketiga dengan analisis jalur dijabarkan pada Gambar 1. (sisipkan Gambar 1 di sini)

Persamaan regresi:

Manajemen Laba $=0,413+0,000$ Debt to Equity Ratio $+0,023$ Ukuran Perusahaan 0,007 Kepemilikan Institusional - 0,009 Kepemilikan Publik 0,069 Dewan Komisaris Independen + 0,017 Komite Audit - 0,007 Profitabilitas

Pertama. Pengaruh Debt to Equity Ratio, Ukuran Perusahaan, Kepemilikan Institusional, Kepemilikan Publik, Dewan Komisaris Independen dan Komite Audit terhadap Profitabilitas

Pengaruh Debt to Equity Ratio terhadap Profitabilitas. Berdasarkan hasil penelitian yang diperoleh menunjukkan bahwa variabel debt to equity ratio tidak berpengaruh terhadap profitabilitas. Hasil penelitian ini mendukung hasil penelitian Barus (2013) yang menunjukkan bahwa debt to equity ratio tidak berpengaruh terhadap profitabilitas. Namun, tidak mendukung hasil penelitian yang dilakukan oleh Mahardhika (2016) yang menunjukkan bahwa debt to equity ratio berpengaruh terhadap profitabilitas. Hal ini dikarenakan debt to equity ratio yang tinggi bukan sesuatu yang buruk apabila perusahaan dapat memanfaatkan secara efektif laba yang didapat untuk membayar biaya bunga secara periodik dan dapat memberikan keuntungan. Investor yang menginginkan return yang tinggi akan lebih menyukai perusahaan yang memiliki debt to equity ratio yang tinggi apabila pinjaman tersebut dapat memberikan dampak positif bagi investor. 
Pengaruh Ukuran Perusahaan terhadap Profitabilitas. Berdasarkan hasil penelitian yang diperoleh menunjukkan bahwa variabel ukuran perusahaan tidak berpengaruh terhadap profitabilitas. Hasil penelitian ini mendukung hasil penelitian yang dilakukan oleh Wehdawati (2015) yang menunjukkan bahwa ukuran perusahaan tidak berpengaruh terhadap profitabilitas. Namun, tidak mendukung penelitian yang dilakukan oleh Barus (2013) yang menunjukkan bahwa ukuran perusahaan berpengaruh terhadap profitabilitas. Hal ini dikarenakan perusahaan yang besar pada dasarnya telah memiliki kekuatan finansial untuk mendukung aktivitas perusahaan, namun semakin besar perusahaan, kemungkinan memiliki masalah keagenan yang juga lebih tinggi dibandingkan perusahaan kecil. Di samping itu, perusahaan yang besar juga tidak menjamin dapat memperoleh semakin banyak laba, karena kemampuan perusahaan dalam mendapatkan laba juga ditentukan oleh kemampuan pihak pengelola dalam memanfaatkan sumber daya yang dimilikinya, salah satunya yaitu sumber daya manusia.

Pengaruh Kepemilikan Institusional terhadap Profitabilitas. Berdasarkan hasil penelitian yang diperoleh menunjukkan bahwa variabel kepemilikan institusional tidak berpengaruh terhadap profitabilitas. Hasil penelitian ini mendukung hasil penelitian yang dilakukan oleh Wehdawati (2015) yang menunjukkan bahwa kepemilikan institusional tidak berpengaruh terhadap profitabilitas. Namun bertentangan dengan penelitian Rimardhani (2016) yang menunjukkan bahwa kepemilikan institusional berpengaruh terhadap profitabilitas. Hal ini disebabkan karena kemampuan sebuah perusahaan dalam memperoleh laba lebih didukung oleh smber daya yang dimiliki dan kemampuan pihak pengelola di dalam memanfaatkan sumber daya tersebut dan tidak tergantung pada ada tidaknya pihak institusi yang menjadi pemilik perusahaan. Di samping itu, pihak institusi yang berinvestasi di perusahaan lain pada umumnya lebih bersifat jangka pendek, hal ini disebabkan karena untuk menghindari adanya dana yang menganggur. Di samping itu, hasil penelitian ini dapat menjelaskan bahwa ternyata memang benar bahwa adanya kepemilikan institusional di dalam sebuah perusahaan hanya sebagai cara atau syarat terpenuhinya penerapan tata kelola perusahaan yang baik.

Pengaruh Kepemilikan Publik terhadap Profitabilitas. Berdasarkan hasil penelitian yang diperoleh menunjukkan bahwa variabel kepemilikan publik tidak berpengaruh terhadap profitabilitas. Hasil penelitian ini mendukung hasil penelitian Suhartanto (2015) yang menunjukkan bahwa kepemilikan publik tidak berpengaruh terhadap profitabilitas. Namun bertentangan dengan penelitian yang dilakukan oleh Purba (2004) yang menunjukkan bahwa kepemilikan publik berpengaruh terhadap profitabilitas. Hal ini disebabkan karena pihak publik yang berinvestasi di perusahaan umumnya bersifat jangka pendek atau hanya lebih ke tindakan spekulasi. Di samping itu, investor publik tidak turut dalam mengambil keputusan dalam menjalankan kegiatan operasional perusahaan. Sehingga ada tidaknya pihak publik yang berinvestasi, tidak memberikan dampak terhadap kinerja perusahaan. Di samping itu, kepemilikan saham oleh pihak publik hanyalah sebagai salah satu syarat yang harus dipenuhi oleh setiap perusahaan yang melakukan go public.

Pengaruh Dewan Komisaris Independen terhadap Profitabilitas. Berdasarkan hasil penelitian yang diperoleh menunjukkan bahwa variabel dewan komisaris independen berpengaruh terhadap profitabilitas. Hasil penelitian ini mendukung hasil penelitian Wehdawati (2015) yang menunjukkan bahwa dewan komisaris independen berpengaruh 
terhadap profitabilitas. Namun bertentangan dengan penelitian Candradewi (2016) yang menunjukkan bahwa dewan komisaris independen tidak berpengaruh terhadap profitabilitas. Dewan komisaris independen merupakan anggota komisaris yang tidak terafiliasi dengan manajemen, anggota komisaris lainnya, dan pemegang saham. Adanya dewan komisaris independen, maka kepentingan pemegang saham, baik mayoritas maupun minoritas tidak diabaikan karena komisaris independen lebih bersikap netral terhadap keputusan yang dibuat oleh manajemen, sehingga manajemen akan berusaha mengambil keputusan yang paling tepat untuk meningkatkan profitabilitas perusahaan.

Pengaruh Komite Audit terhadap Profitabilitas. Berdasarkan hasil penelitian yang diperoleh menunjukkan bahwa variabel komite audit tidak berpengaruh terhadap profitabilitas. Hasil penelitian ini mendukung hasil penelitian Rimardhani (2016) yang menunjukkan bahwa komite audit tidak berpengaruh terhadap profitabilitas. Namun bertentangan dengan penelitian Rini (2012) yang menunjukkan bahwa komite audit berpengaruh terhadap profitabilitas. Tidak adanya pengaruh dari komite audit dalam suatu perusahaan dikarenakan peran dari komite audit kurang optimal dalam menjalankan fungsi pengawasan dan pengendalian pada manajemen perusahaan. Selain itu, dalam memelihara kualitas laporan keuangan dan membantu dewan komisaris independen belum sepenuhnya tercapai oleh komite audit sehingga belum mampu meningkatkan profitabilitas perusahaan. Pemilihan anggota komite audit masih berdasarkan kekerabatan sehingga pemantauan terhadap dewan direksi kurang maksimal.

\section{Kedua. Pengaruh Debt to Equity Ratio, Ukuran Perusahaan, Kepemilikan Institusional, Kepemilikan Publik, Dewan Komisaris Independen, Komite Audit, dan Profitabilitas terhadap Manajemen Laba}

Pengaruh Debt to Equity Ratio terhadap Manajemen Laba. Berdasarkan hasil penelitian yang diperoleh menunjukkan bahwa variabel debt to equity ratio tidak berpengaruh terhadap manajemen laba. Hasil penelitian mendukung penelitian Pradipta (2011) yang menunjukkan bahwa debt to equity ratio tidak berpengaruh terhadap manajemen laba. Namun tidak mendukung penelitian yang dilakukan oleh Afriandi dan Wahidahwati (2013) yang menunjukkan bahwa debt to equity ratio berpengaruh terhadap manajemen laba. Hal ini dikarenakan perusahaan dengan debt to equity ratio yang semakin tinggi bukan berarti bad news karena ada kemungkinan terjadi perluasan usaha yang dilakukan oleh perusahaan sehingga meskipun terjadi penggunaan hutang yang lebih banyak, tidak mendorong manajer melakukan tindakan manajemen laba, karena ada target-target atau rencana yang ingin dicapai oleh perusahaan yang pada jangka panjang akan memberikan manfaat kepada pemilik.

Pengaruh Ukuran Perusahaan terhadap Manajemen Laba. Berdasarkan hasil penelitian yang diperoleh menunjukkan bahwa variabel ukuran perusahaan tidak berpengaruh terhadap manajemen laba. Hasil penelitian mendukung penelitian yang dilakukan oleh Sosiawan (2012) yang menunjukkan bahwa ukuran perusahaan tidak berpengaruh terhadap manajemen laba. Namun tidak mendukung penelitian yang dilakukan oleh Sirat (2012) yang menunjukkan bahwa ukuran penelitian berpengaruh terhadap manajemen laba. Hal ini dikarenakan bahwa motivasi dewan direksi untuk melakukan manajemen laba bukan didasarkan pada ukuran perusahaan. Baik perusahaan besar maupun perusahaan kecil akan tetap memiliki kemungkinan untuk melakukan manajemen laba ketika pengawasan yang dilakukan kurang mendukung. 
Pengaruh Kepemilikan Institusional terhadap Manajemen Laba. Berdasarkan hasil penelitian yang diperoleh menunjukkan bahwa variabel kepemilikan institusional berpengaruh terhadap manajemen laba. Hasil penelitian mendukung penelitian yang dilakukan oleh Widyastuti (2009) yang menunjukkan bahwa kepemilikan institusional berpengaruh terhadap manajemen laba. Namun, tidak mendukung penelitian yang dilakukan oleh Agustia (2013) yang menunjukkan bahwa keepemilikan institusional tidak berpengaruh terhadap manajemen laba. Hal ini dikarenakan investor institusional dapat memaksimalkan peranannya dalam melakukan pengawasan dan pengendalian di didalam perusahaan. Sehingga manajer memiliki kesempatan yang lebih kecil untuk mencoba mengatur jumlah laba yang akan dilaporkan, karena adanya pengawasan yang lebih ketat dari pihak institusional.

Pengaruh Kepemilikan Publik terhadap Manajemen Laba. Berdasarkan hasil penelitian yang diperoleh menunjukkan bahwa variabel kepemilikan publik berpengaruh terhadap manajemen laba. Hal ini tidak mendukung penelitian yang dilakukan oleh Suhartanto (2015) yang menunjukkan bahwa kepemilikan publik tidak berpengaruh terhadap manajemen laba. Hal ini dikarenakan semakin tinggi persentase saham yang ditawarkan kepada publik maka semakin besar pula informasi yang harus disajikan manajer kepada publik sehingga manajer dituntut untuk menyajikan informasi yang baik sehingga menarik minat investor untuk melakukan investasi. Investor publik mengakibatkan manajer berkewajiban memberikan informasi internal secara berkala sebagai bentuk pertanggungjawabannya sehingga kemungkinan dapat mengurangi intensitas terjadinya manajemen laba karena adanya pengawasan dari investor publik tersebut. Hal ini menunjukkan bahwa semakin tinggi kepemilikan publik, maka akan semakin rendah manajemen laba.

Pengaruh Dewan Komisaris Independen terhadap Manajemen Laba. Berdasarkan hasil penelitian yang diperoleh menunjukkan bahwa variabel dewan komisaris independen tidak berpengaruh terhadap manajemen laba. Hasil penelitian mendukung penelitian yang dilakukan oleh Agustia (2013) yang menunjukkan bahwa dewan komisaris independen tidak berpengaruh terhadap manajemen laba. Namun, tidak mendukung penelitian yang dilakukan oleh Rahmawati (2013) yang menunjukkan bahwa dewan komisaris independen berpengaruh terhadap manajemen laba. Hasil penelitian menunjukkan bahwa ukuran dewan komsaris independen tidak memiliki kemampuan untuk mengendalikan pihak manajemen sehingga tidak dapat mengurangi manajemen laba. Dewan komisaris independen tidak berpengaruh signifikan terhadap manajemen laba, hal ini dikarenakan dewan komisaris independen ditunjuk oleh pemegang saham mayoritas dalam rapat umum pemegang saham sehingga apabila tidak sejalan dengan keputusan pemilik, maka perusahaan dapat melakukan penggantian. Pada praktiknya, meskipun komposisi dewan komisaris independen pada perusahaan relatif besar, tetapi mereka tidak dapat benar benar independen dalam menjalankan tugas dan pengawasannya karena terbatas oleh peraturan atau kebijakan dari pemegang saham mayoritas.

Pengaruh Komite Audit terhadap Manajemen Laba. Berdasarkan hasil penelitian yang diperoleh menunjukkan bahwa variabel komite audit tidak berpengaruh terhadap manajemen laba. Hasil penelitian mendukung penelitian yang dilakukan oleh Rahmawati (2013) yang menunjukkan bahwa komite audit tidak berpengaruh terhadap manajemen laba. Namun, tidak mendukung penelitian yang dilakukan oleh Suriyani et al (2015) yang 
menunjukkan bahwa komite audit berpengaruh terhadap manajemen laba. Hal ini dikarenakan besar kecilnya komite audit bukanlah menjadi faktor penentu utama efektivitas pengawasan terhadap manajemen perusahaan. Hasil yang tidak signifikan menunjukkan bahwa keberadaan komite audit belum mengurangi tindakan manajemen laba.

Ketiga. Pengaruh Debt to Equity Ratio, Ukuran Perusahaan, Kepemilikan Institusional, Kepemilikan Publik, Dewan Komisaris Independen, dan Komite Audit terhadap Manajamen Laba melalui Profitabilitas.

Pengaruh Debt to Equity Ratio terhadap Manajemen Laba melalui Profitabilitas. Berdasarkan hasil analisis jalur diketahui bahwa profitabilitas tidak dapat memediasi pengaruh antara debt to equity ratio terhadap manajemen laba. Hal ini terlihat bahwa secara langsung, debt to equity ratio tidak berpengaruh terhadap manajemen laba dan profitabilitas. Ini menunjukkan bahwa besar kecilnya debt to equity ratio tidak dapat mempengaruhi perusahaan di dalam melakukan kegiatan untuk meningkatkan profitabilitas sehingga tidak dapat mempengaruhi perusahaan dalam melakukan tindakan manajemen laba.

Pengaruh Ukuran Perusahaan terhadap Manajemen Laba melalui Profitabilitas. Berdasarkan hasil analisis jalur diketahui bahwa profitabilitas tidak dapat memediasi pengaruh antara ukuran perusahaan terhadap manajemen laba. Hal ini terlihat bahwa secara langsung, ukuran perusahaan tidak berpengaruh terhadap manajemen laba dan profitabilitas. Ini menunjukkan bahwa besar kecilnya ukuran perusahaan tidak dapat mempengaruhi perusahaan di dalam melakukan kegiatan untuk meningkatkan profitabilitas sehingga tidak dapat mempengaruhi perusahaan dalam melakukan tindakan manajemen laba.

Pengaruh Kepemilikan Institusional terhadap Manajemen Laba melalui Profitabilitas. Berdasarkan hasil analisis jalur diketahui bahwa profitabilitas dapat memediasi kepemilikan insitusional terhadap manajemen laba. Hal ini dapat dilihat bahwa secara langsung, kepemilikan institusional berpengaruh terhadap manajemen laba, namun tidak berpengaruh terhadap profitabilitas. Hal ini menunjukkan bahwa fungsi dari pengendalian pihak institusi dapat mendorong perusahaan dalam mencapai tingkat profitabilitas yang tinggi. Selain itu, investor institusional memiliki sumber daya yang baik dalam melakukan fungsi pengawasan terhadap tindakan manajer perusahaan, sehingga semakin besar jumlah kepemilikan saham oleh investor institusional akan lebih mampu dalam membatasi praktek manajemen laba yang dilakukan oleh manajer perusahaan.

Pengaruh Kepemilikan Publik terhadap Manajemen Laba melalui Profitabilitas. Berdasarkan hasil analisis jalur diketahui bahwa profitabilitas dapat memediasi kepemilikan publik terhadap manajemen laba. Hal ini dapat dilihat bahwa secara langsung, kepemilikan publik berpengaruh terhadap manajemen laba, namun tidak berpengaruh terhadap profitabilitas. Hal ini menunjukkan bahwa semakin besar kepemilikan publik, maka semakin rendah manajemen laba perusahaan. Manajemen perusahaan publik akan memiliki keinginan yang lebih besar dalam memperoleh laba yang maksimal, sehingga 
akan mengawasi perusahaan dalam kinerjanya untuk mencapai tingkat profitabilitas dan keandalan informasi keuangan yang diharapkan oleh investor.

Pengaruh Dewan Komisaris Independen terhadap Manajemen Laba melalui Profitabilitas. Berdasarkan hasil analisis jalur diketahui bahwa profitabilitas dapat memediasi dewan komisaris independen terhadap manajemen laba. Hal ini terlihat bahwa meskipun secara langsung, dewan komisaris independen tidak berpengaruh terhadap manajemen laba, namun ternyata dewan komisaris independen berpengaruh terhadap profitabilitas. Hal ini dikarenakan dewan komisaris independen bertindak sebagai penengah dalam perselisihan yang terjadi diantara manajer internal dan mengawasi kebijakan manajemen serta memberikan nasihat kepada manajemen dalam upaya peningkatan profitabilitas.

Pengaruh Komite Audit terhadap Manajemen Laba melalui Profitabilitas. Berdasarkan hasil analisis jalur diketahui bahwa profitabilitas tidak dapat memediasi pengaruh antara komite audit terhadap manajemen laba. Hal ini terlihat bahwa secara langsung, komite audit tidak berpengaruh terhadap manajemen laba dan profitabilitas. Ini menunjukkan bahwa besar kecilnya komite audit tidak dapat mempengaruhi perusahaan di dalam melakukan kegiatan untuk meningkatkan profitabilitas sehingga tidak dapat mempengaruhi perusahaan dalam melakukan tindakan manajemen laba.

\section{PENUTUP}

Simpulan. Secara simultan, debt to equity ratio, ukuran perusahaan, kepemilikan institusional, kepemilikan publik, dewan komisaris independen, komite audit, berpengaruh terhadap profitabilitas. Secara parsial, hanya dewan komisaris independen berpengaruh terhadap profitabilitas. Sedangkan variabel debt to equity ratio, ukuran perusahaan, kepemilikan institusional, kepemilikan publik, dan komite audit tidak berpengaruh terhadap profitabilitas.

Secara simultan, variabel debt to equity ratio, ukuran perusahaan, kepemilikan institusional, kepemilikan publik, dewan komisaris independen, komite audit, dan profitabilitas berpengaruh terhadap manajemen laba. Secara parsial, hanya variabel kepemilikan institusional dan kepemilikan publik yang berpengaruh terhadap manajemen laba. Sedangkan variabel debt to equity ratio, ukuran perusahaan, dewan komisaris independen, komite audit, dan profitabilitas tidak berpengaruh terhadap manajemen laba.

Profitabilitas hanya dapat memediasi pengaruh kepemilikan institusional, kepemilikan publik, dan dewan komisaris independen terhadap manajemen laba, namun tidak dapat memediasi pengaruh debt to equity ratio, ukuran perusahaan, dan komite audit terhadap manajemen laba.

Saran. Untuk peneliti selanjutnya disarankan dapat menambah variabel lain yang lebih dapat menjelaskan pengaruhnya terhadap profitabilitas dan manajemen laba. Peneliti selanjutnya dapat menambahkan variabel tipe industri, karena adanya perbedaan tipe industri memungkinkan adanya perbedaan pula dalam tindakan manajemen laba.Selain itu, disarankan untuk melakukan pengujian secara rinci pada variabel struktur kepemilikan selain kepemilikan institusional dan kepemilikan publik seperti kepemilikan asing, 
kepemilikan domestik, dan kepemilikan manajerial agar dapat mengetahui struktur kepemilikan mana yang dapat berpengaruh terhadap profitabilitas dan manajemen laba.

\section{DAFTAR RUJUKAN}

Afriandi, D. D. dan Wahidahwati, (2013). "Pengaruh Kinerja Keuangan terhadap Manajemen Laba Perusahaan yang Melakukan Initial Public Offering (IPO)", Jurnal Ilmu dan Riset Akuntansi, 2(9), 1-17.

Agustia, D., (2013). "Pengaruh Faktor Good Corporate Governance, Free Cash Flow, dan Leverage Terhadap Manajemen Laba", Jurnal Akuntansi dan Keuangan, 15(1), 27 42.

Andawiyah, S.R. dan Astri Furqani, (2016)."Faktor - faktor yang Mempengaruhi Manajemen Laba pada Perusahaan Sub Sektor Otomotif dan Komponen yang Terdaftar di Bursa Efek Indonesia”, Jurnal Performance Bisnis dan Akuntansi, $\mathrm{VI}(2), 1-11$.

Barus, A.C. dan Leliani, (2013). "Analisis Faktor - faktor yang Mempengaruhi Profitabilitas pada Perusahaan Manufaktur yang Terdaftar di Bursa Efek Indonesia", Jurnal Wira Ekonomi Mikroskil, 3(02), 1-11.

Candradewi, I. dan Ida Bagus Panji Sedana, (2016). "Pengaruh Kepemilikan Manajerial, Kepemilikan Institusional, dan Dewan Komisaris Independen terhadap Return On Asset", E- Jurnal Manajemen Unud, 5(5),1-28.

Darsono, R. dan Ashari, (2005). "Pedoman Praktis Memahami Laporan Keuangan", Penerbit Andi, Yogyakarta.

Gunawan, I. K. Nyoman Ari Surya Darmawan, dan I Gusti Ayu Purnamawati, (2015). "Pengaruh Ukuran Perusahaan, Profitabilitas, dan Leverage terhadap Manajamen Laba pada Perusahaan Manufaktur yang Terdaftar di Bursa Efek Indonesia (BEI), Jurnal Akuntansi, 3(1), 1-10.

Mahardhika, P.A. dan D. P. Marbun, (2016). "Pengaruh Current Ratio dan Debt to Equity Ratio terhadap Return On Assets", Jurnal Widyakala, 3:1-6.

Mohamed, T., Ben Jemaa Olfa, and Jilani Faouzi, (2014). "Corporate Social Disclosure : Explanatory Theories and Conceptual Framework", International Journal of Academic Research in Management (IJARM), 3(2), 208-225.

Pradipta, A., (2011). "Analisis Pengaruh dari Mekanisme Corporate Governance terhadap Manajemen Laba", Jurnal Bisnis dan Akuntansi, 13(2), 93-106.

Purba, J.H.V., (2004). "Pengaruh Proporsi Saham Publik terhadap Kinerja Perusahaan", Jurnal Ilmiah Ranggagading, 4(2), 109-116.

Rini, T.S. dan Imam Ghozali, (2012). "Pengaruh Pemegang Saham Institusi, Komsiarsi Independen, dan Komite Audit terhadap Tingkat Profitabilitas Perusahaan", Diponegoro Journal of Accounting, 1(1), 1-12.

Rahmawati, H.I., (2013). "Pengaruh Good Corporate Governance (GCG) terhadap Manajemen Laba pada Perusahaan Perbankan", Accounting Analysis Journal, 2(1):1-10.

Rimardhani, H., R. Rustam Hidayat dan Dwiatmanto, (2016). "Pengaruh Mekanisme Good Corporate Governance terhadap Profitabilitas Perusahaan", Jurnal Administrasi Bisnis, 31(1), 1-9. 
Sirat, H. (2012). "Corporate Governance Practices, Share Ownership Structure, and Size on Earning Management", Journal of Economics, Business, and Accountancy Ventura, 15(1), 145-156.

Subramanyam, K.R. dan John J. Wild, (2010). "Analisis Laporan Keuangan”, Alih Bahasa : Dewi Yanti, Buku 1, Edisi 10, Penerbit Salemba Empat, Jakarta.

Suriyani, P.P., Gede Adi Yuniarta, Ananta WikramaT.A., (2015). "Faktor - faktor yang Mempengaruhi Manajemen Laba", Jurnal Akuntansi, 3(1), 1-11.

Sosiawan, S.Y., (2012). "Pengaruh Kompensasi, Leverage, Ukuran Perusahaan, Earning Power terhadap Manajemen Laba", Jurnal Riset Akuntansi Keuangan, 8(1), 1-11.

Syahyunan, (2015). "Manajemen Keuangan-Perencanaan, Analisis dan Pengendalian Keuangan", Edisi kedua, Penerbit USU Press, Medan.

Suhartanto,D., (2015). "Pengaruh Ukuran Perusahaan, Profitabilitas, Leverage, Kepemilikan Publik, Perubahan Harga Saham dan Risiko Bisnis terhadap Manajemen Laba pada Perusahaan Publik Sektor Keuangan”, Jurnal Ekonomi Bisnis, $20(1), 1-7$.

Widyastuti, T., (2009). "Pengaruh Struktur Kepemilikan dan Kinerja Keuangan terhadap Manajemen Laba: Studi pada Perusahaan Manufaktur di Bursa Efek Indonesia", Jurnal MAKSI, 9(1), 30-41.

Wehdawati, Fifi Swandari dan Sufi Jikrillah, (2015). "Pengaruh Mekanisme Good Corporate Governance dan Struktur Kepemilikan terhadap Kinerja Keuangan Perusahaan Manufaktur yang Terdaftar di Bursa Efek Indonesia Tahun 2010 - 2012”, Jurnal Wawasan Manajemen”, 3(3), 1-12.

www.idx.co.id 
Tabel 1. Statistik Deskriptif

\begin{tabular}{lcrrrr}
\hline & N & Minimum & Maximum & \multicolumn{1}{c}{ Mean } & Std. Deviation \\
\hline Profitabilitas & 84 & -145.6977 & 39.4769 & 2.750414 & 20.6597145 \\
ManajemenLaba & 84 & -2.6203 & 1.8740 & -.149414 & .4222745 \\
Debt to Equity Ratio & 84 & .0040 & 680.2499 & 138.291435 & 137.9165197 \\
Ukuran Perusahaan & 84 & 11.9640 & 17.2717 & 15.354792 & 1.4255674 \\
KepemilikanInstitusional & 84 & 13.0000 & 98.1786 & 62.586046 & 18.2172115 \\
KepemilikanPublik & 84 & 1.8214 & 83.4646 & 34.149269 & 16.9392195 \\
DewanKomisarisIndependen & 84 & 1 & 5 & 1.82 & .920 \\
KomiteAudit & 84 & 3 & 6 & 3.27 & .647 \\
Valid N (listwise) & 84 & & & & \\
\hline
\end{tabular}

Tabel 2. Hasil Pengujian Hipotesis

\begin{tabular}{|c|c|c|c|c|c|c|}
\hline & \multicolumn{3}{|c|}{ Model 1 (Profitabilitas) } & \multicolumn{3}{|c|}{ Model 2 (Manajemen Laba) } \\
\hline & B & $\mathbf{t}$ & Sig & B & $\mathbf{t}$ & Sig \\
\hline & 15,277 & 1,018 &, 312 & 4,413 & 955 &, 343 \\
\hline DER &,- 008 &,- 893 & 375 & 000 &,- 968 & 337 \\
\hline UkuranPerusahaan &,- 406 &,- 469 & 641 & ,023 & ,922 & ,360 \\
\hline KepInstitusional & ,039 & ,411 & 683 &,- 007 & $-2,614$ & ,011 \\
\hline KepPublik &,- 146 & $-1,460$ & ,149 &,- 009 & $-3,268$ & ,002 \\
\hline DewanKomisarisIndependen & 3,115 & 2,190 & ,032 &,- 069 & $-1,637$ & ,106 \\
\hline KomiteAudit & $-1,589$ &,- 836 & ,406 & ,017 & ,312 & ,756 \\
\hline ROA & & & &,- 007 & $-1,659$ &, 102 \\
\hline $\mathrm{F}(\mathrm{Sig})$ & & ,006 & & & ,038 & \\
\hline F hitung & & 3,336 & & & 2,290 & \\
\hline Adjusted R Square & & ,157 & & & ,110 & \\
\hline$R$ Square & & 225 & & & ,195 & \\
\hline
\end{tabular}

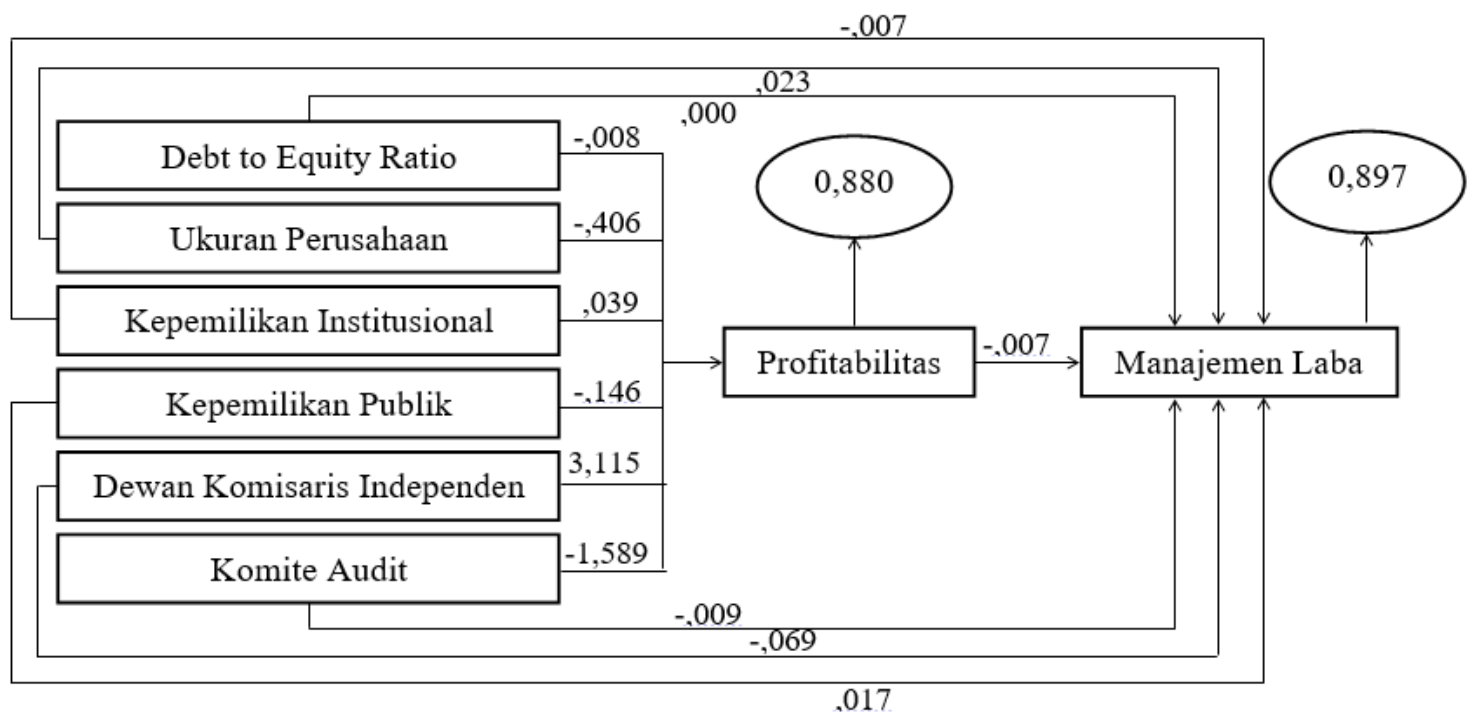

Gambar 1. Model Pengujian Pengaruh Debt to Equity Ratio, Ukuran Perusahaan, Kepemilikan Institusional, Kepemilikan Publik, Dewan Komisaris Independen, 
Komite Audit terhadap Profitabilitas dan dampaknya terhadap Manajemen Laba 